\title{
A Longitudinal Study of the Well-being of Students Using the Student Wellbeing Process Questionnaire (Student WPQ)
}

\author{
Gary Williams ${ }^{1}$ and Andrew P. Smith ${ }^{1^{*}}$ \\ ${ }^{1}$ Centre for Occupational and Health Psychology, School of Psychology, Cardiff University, 63 Park \\ Place, Cardiff, CF24 ODB, United Kingdom.
}

Authors' contributions

This work was carried out in collaboration between both authors. They were both involved in the design, data collection, statistical analysis and writing of the manuscript. Both authors read and approved the final manuscript.

Article Information

DOI: $10.9734 / J E S B S / 2018 / 40105$

Editor(s):

(1) Doutora Laurinda Leite, Professor, Institute of Education, University of Minho, Portugal.

Reviewers:

(1) Hakan Usakli, Sinop University, Turkey.

(2) Mikaella Symeou Konstantinou, Frederick University of Cyprus, Cyprus. Complete Peer review History: http://www.sciencedomain.org/review-history/23889

Short Research Article

Received $19^{\text {th }}$ January 2018

Accepted $26^{\text {th }}$ March 2018

Published $30^{\text {th }}$ March 2018

\section{ABSTRACT}

Background: Previous research shows that the Student Well-being Process Questionnaire (Student WPQ) has good content validity, construct validity, and discriminate validity.

Objective: The present research examined the reliability and predictive validity of the Student WPQ scales.

Method: Eighty-seven university undergraduate and postgraduate students aged 18-47 years participated in a longitudinal study which involved completing an online survey twice, with the sessions being 10 weeks apart. The data were used to assess the test-re-test reliability and the predictive validity of the scales.

Results: Positive personality and social support had high test-re-test reliability and demands and negative coping had slightly lower reliability suggesting that the WPQ measures both stable traits and changes in state. Cross-sectional analyses confirmed that the predictor variables were associated with wellbeing outcomes. Cross-lag analysis showed that the positive personality and 
demands at time 1 predicted wellbeing at time 2. Changes in positive personality predicted changes in wellbeing.

Conclusion: These findings show that the student WPQ has good test-re-test reliability and can be used in longitudinal studies which give a stronger indication of causality.

Keywords: Reliability; predictive validity; well-being; student WPQ.

\section{INTRODUCTION}

The Well-Being Process Questionnaire [1,2,3] uses short scales to measure both positive (e.g. happiness, positive affect, and life satisfaction) and negative (stress, anxiety, and depression) aspects of well-being and predictors of these outcomes. It was developed from the DemandsResources-Individual Effects (DRIVE) model [4, $5,6]$ and has been used with samples of workers $[3,7,8]$. Research using the WPQ has led to the development of another questionnaire (the Smith Well-being Questionnaire - SWELL [9,10,11, 12,13] which measures a wider range of predictors (e.g. addition of questions on the working environment and hours of work) and outcomes (e.g. absenteeism; presenteeism; sick leave; performance efficiency; work-life balance and illness caused or made worse by work).

Williams, Thomas, and Smith [8] examined correlations between the single items in the WPQ and the longer scales from which they were derived. The average same-variable correlations for each variable group (full-scale $v$ single item) were .66 (work characteristics), .63 (personality), .37 (coping style) and .63 (outcomes), suggesting good concurrent validity (above .50) in all but coping style. Many of the single-item measures had comparable estimates with the alpha reliability of their multi-item counterpart (e.g. Demands .71 (single-item) .77 (multi-item) and supervisor relationship .92 (single-item) .94 (multi-item)).

The well-being of university students has also been studied for a long time [14] and high levels of mental health problems have been reported in undergraduate students $[15,16]$. Many of the same concepts in the WPQ have also been applied in this research. A student version has been developed [17] and this has also been shown to have good construct validity.

Most of the studies that have used the WPQ have had cross-sectional designs which makes interpretation of causality difficult. Galvin [18] carried out a longitudinal study and showed the predictive value of the WPQ scales in a sample of clinical students. The aim of the present study was to examine the test-re-test reliability of the Student WPQ scales in a short longitudinal study (10 weeks). It also examined whether measures taken at time one could predict outcomes at time 2 (a cross-lag analysis) and whether changes in predictors were associated with changes in wellbeing.

\section{METHODS}

This study was carried out with the approval of the ethics committee, School of Psychology, Cardiff University, and the informed consent of the volunteers.

\subsection{Participants}

Eighty-seven undergraduate and postgraduate students aged 18 to 47 years from across the university took part in the study. Mean age was 21 years, 75\% were female. The majority (71\%) identified as white, with the remaining identifying as Indian (2\%) or Chinese (17\%). Nine percent did not indicate ethnicity.

\subsection{Design}

Short-term longitudinal design over 10 weeks.

\subsection{Materials}

Single-item measures of positive personality (self-efficacy; self-esteem; and optimism) social support (esteem support; tangible support; belonging support; and emotional support), student-focused demands (challenges to your development; time pressure; academic dissatisfaction; romantic problems; societal annoyance; social mistreatment; and friendship problems) and negative coping (wishful thinking; blame self; and avoidance) were the well-being predictors. The wellbeing outcomes covered positive items (happiness, positive affect, and life satisfaction) and negative ones (life stress, anxiety and depression). An overall wellbeing score was calculated by subtracting the sum of the negative items from the sum of the positive ones. All items were responded to using a 10 
point rating scale. The actual questions are shown in [8].

\subsection{Procedure}

The study was advertised on the university notice board and those interested were provided with further information and a unique identifier in order to link responses at each time point. Scores at time 1 were taken 4 weeks into the academic year, those at time 2 were taken 10 weeks later. Each stage of the study included a consent and instructions sheet at the beginning of the questionnaire and respondents could not continue beyond the consent form on the first page before consenting to participate. Debrief was presented at the end of the final stage of the research. Respondents were paid $£ 5$ at the completion of each time period. Ethical approval was provided by Cardiff University Psychology Department Ethics Committee.

\subsection{Analysis Procedure}

Test-retest correlations were used to assess the stability of scores on the scales at 10 weeks (time 1 - time 2). Cross-sectional analyses of the time 1 and time 2 data were used to assess the associations between the predictor variables and the outcomes. A cross-lag analysis was carried out to examine associations between the time 1 predictors and time 2 outcomes. Changes between time one and time two were calculated and associations between changes in the predictors and outcomes examined.

\section{RESULTS}

Table 1 shows the test-re-test correlations for the predictor variables and the well-being outcome score. All of these correlations were significant showing some stability over time. This was especially true for the positive personality score and the social support score, although even variables that one might expect to reflect current state (e.g. demands and well-being) showed quite high test-re-test correlations.

Cross-sectional analyses were carried out on the time 1 and time 2 data. These results are shown in Tables 2 and 3. At time 1, well-being was predicted by positive personality and demands, whereas at time 2 well-being was predicted by these variables and social support.

The next analysis (a cross-lag analysis) examined whether scores at time 1 predicted well-being at time 2 (see Table 4). These results showed that positive personality was the strongest predictor of positive well-being.

A final analysis examined change scores (time 2time 1). These results are shown in Table 5. Once again, positive personality (changes in positive personality) predicted positive well-being (changes in positive well-being).

Table 1. Test-retest correlations

\begin{tabular}{|c|c|c|c|c|c|}
\hline \multirow[t]{2}{*}{ Time 2 scores } & \multicolumn{5}{|c|}{ Time 1 scores } \\
\hline & $\begin{array}{l}\text { Positive } \\
\text { personality }\end{array}$ & Demands & $\begin{array}{l}\text { Social } \\
\text { support }\end{array}$ & Negative coping & Well-being \\
\hline $\begin{array}{l}\text { Positive personality } \\
\text { Demands }\end{array}$ & 0.68 & 0.45 & & & \\
\hline Social support & & & 0.70 & & \\
\hline $\begin{array}{l}\text { Negative coping } \\
\text { Well-being }\end{array}$ & & & & 0.60 & 0.68 \\
\hline
\end{tabular}

Table 2. Cross-sectional analysis at time 1 (dependent variable = time 1 well-being)

\begin{tabular}{|c|c|c|c|c|c|}
\hline \multicolumn{6}{|c|}{ Coefficients } \\
\hline \multirow[t]{2}{*}{ Model } & \multicolumn{2}{|c|}{$\begin{array}{c}\text { Unstandardized } \\
\text { coefficients }\end{array}$} & $\begin{array}{l}\text { Standardized } \\
\text { coefficients }\end{array}$ & $\mathbf{t}$ & Sig. \\
\hline & B & Std. error & Beta & & \\
\hline $1 \quad$ (Constant) & -15.653 & 6.902 & & -2.268 & .026 \\
\hline t1 positive personality & 1.181 & .178 & .545 & 6.641 & .000 \\
\hline $\mathrm{t} 1$ demands & -.262 & .095 & -.248 & -2.759 & .007 \\
\hline t1 social support & .210 & .179 & .096 & 1.177 & .242 \\
\hline t1 negative coping & -.139 & .176 & -.068 & -.788 & .433 \\
\hline
\end{tabular}


Table 3. Cross-sectional analysis at time 2 (dependent variable $=$ time 2 well-being)

\begin{tabular}{lllllll}
\hline Model & \multicolumn{3}{c}{$\begin{array}{c}\text { Coefficients } \\
\text { Unstandardized } \\
\text { coefficients }\end{array}$} & $\begin{array}{l}\text { Standardized } \\
\text { coefficients }\end{array}$ & t & Sig. \\
\cline { 2 - 4 } & B & Std. error & Beta & & \\
\hline 1 & (Constant) & -26.672 & 6.421 & & -4.154 & .000 \\
& T2 positive personality & 1.294 & .151 & .640 & 8.563 & .000 \\
& T2 demands & -.230 & .080 & -.210 & -2.873 & .005 \\
T2 social support & .379 & .166 & .157 & 2.281 & .025 \\
T2 negative coping & -.036 & .138 & -.019 & -.261 & .795 \\
\hline
\end{tabular}

Table 4. Cross-lag analysis (time 1 predictors; dependent variable $=$ time 2 well-being)

\begin{tabular}{|c|c|c|c|c|c|}
\hline \multirow{3}{*}{ Model } & \multicolumn{3}{|c|}{ Coefficients } & \multirow{3}{*}{$\mathbf{t}$} & \multirow{3}{*}{ Sig. } \\
\hline & \multicolumn{2}{|c|}{$\begin{array}{l}\text { Unstandardized } \\
\text { coefficients }\end{array}$} & $\begin{array}{l}\text { Standardized } \\
\text { coefficients }\end{array}$ & & \\
\hline & B & Std. error & Beta & & \\
\hline 1 (Constant) & -31.201 & 7.455 & & -4.185 & .000 \\
\hline T1 Positive Personality & 1.317 & .193 & .589 & 6.826 & .000 \\
\hline T2 Demands & -.104 & .103 & -.096 & -1.011 & .315 \\
\hline T2 Social Support & .381 & .193 & .168 & 1.968 & .053 \\
\hline T2 Negative Coping & .012 & .192 & .006 & .065 & .948 \\
\hline
\end{tabular}

Table 5. Change-score analysis

\begin{tabular}{|c|c|c|c|c|c|c|}
\hline \multicolumn{7}{|c|}{ Coefficients } \\
\hline \multirow{2}{*}{\multicolumn{2}{|c|}{ Model }} & \multicolumn{2}{|c|}{$\begin{array}{c}\text { Unstandardized } \\
\text { coefficients }\end{array}$} & \multirow{2}{*}{$\begin{array}{l}\text { Standardized } \\
\text { coefficients } \\
\text { Beta }\end{array}$} & \multirow[t]{2}{*}{$\mathbf{t}$} & \multirow[t]{2}{*}{ Sig. } \\
\hline & & B & Std. error & & & \\
\hline \multirow[t]{5}{*}{1} & (Constant) & -1.454 & .797 & & -1.824 & .072 \\
\hline & Demands change & -.124 & .077 & -.152 & -1.614 & .110 \\
\hline & Negative coping change & -.291 & .161 & -.167 & -1.802 & .075 \\
\hline & Positive Personality change & 1.076 & .188 & .515 & 5.723 & .000 \\
\hline & Social support change & .056 & .218 & .024 & .257 & .798 \\
\hline
\end{tabular}

\section{DISCUSSION}

The present study aimed to continue to extend the use of an adapted DRIVE model and the use of the WPQ to a student sample. A measure of student-specific demands was used and a measure of social support created [17]. Other measures (coping and personality) were from the original WPQ. The results from a previous crosssectional study [17] showed that these measures could predict both positive and negative outcomes. In the cross-sectional study, there was no evidence of interactions between the variables and a combined effects score was calculated by summing the predictors. All three outcomes showed the predicted changes across the quartiles of the combined effects score. Overall, these cross-sectional results confirm that a short measuring instrument can demonstrate predicted variation in well-being measures. A limitation of the original student WPQ was that it was cross-sectional and it was suggested that a longitudinal study was highly desirable.

The study described in this article is the first to use the Student WPQ in a longitudinal study. The test-re-test correlations for the predictor variables and the well-being outcome score were all significant. Cross-sectional, cross-lag and change score analyses all showed significant effects of the predictor variables, with positive personality being the strongest predictor of positive well-being. Future research can extend the present approach by examining individual components of well-being in more detail. Similarly, other dimensions can be incorporated into the research to investigate the influence of lifestyle (e.g. diet, exercise, sleep, alcohol, and drugs) and mental fatigue [19], while controlling for the established predictors studied here. 
Another extension will be to use the WPQ in intervention studies which aim to promote positive well-being or reduce negative outcomes such as stress, anxiety, and depression.

\section{CONCLUSIONS}

In summary, the present study has shown that the Student WPQ has good test-re-test reliability. Similar results were found in the cross-sectional analyses of the two-time points, cross-lag analyses, and change score analyses. Positive personality (high levels of optimism, self-efficacy, and self-esteem) was found to be the strongest predictor of positive well-being in all of the analyses.

\section{COMPETING INTERESTS}

Authors have declared that no competing interests exist.

\section{REFERENCES}

1. Williams GM. Researching and developing mental health and wellbeing assessment tools for supporting employees and employers in Wales. Ph.D. thesis. Cardiff University; 2015.

Available:http://orca.cf.ac.uk/71443/1/2015 williamsphd.pdf

2. Williams G, Smith AP. A holistic approach to stress and well-being. Part 6: The Wellbeing Process Questionnaire (WPQ Short Form). Occupational Health [At Work. 2012;9(1):29-31.

3. Williams GM, Smith AP. Using single-item measures to examine the relationships between work, personality, and well-being in the workplace. Psychology: Special Edition on Positive Psychology. 2016;7: 753-767.

DOI:10.4236/psych.2016.76078

Available:http://file.scirp.org/pdf/PSYCH 2 016060115074176.pdf

4. Mark GM, Smith AP. Stress models: A review and suggested a new direction. In: Houdmont J. \& Leka S. (eds.) Occupational Health Psychology: European Perspectives on research, education, and practice. EA-OHP series. Nottingham University Press. 2008;3111144.

5. Mark G, Smith AP. Effects of occupational stress, job characteristics, coping and attributional style on the mental health and job satisfaction of university employees.
Anxiety, Stress, and Coping. 2011;25:6378.

DOI: $10.1080 / 10615806.2010 .548088$

6. Mark G, Smith AP. Occupational stress, job characteristics, coping and mental health of nurses. British Journal of Health Psychology. 2012;17:505-521.

DOI: 10.1111/j.2044-8287.2011.02051.x

7. Williams G, Pendlebury $H$, Smith AP. Stress and well-being of nurses: An investigation using the DemandsResources- Individual Effects (DRIVE) model and well-being process questionnaire (WPQ). Jacobs Journal of Depression and Anxiety. 2017;1:1-8.

8. Williams G, Thomas K, Smith AP. Stress and well-being of University Staff: An investigation using the DemandsResources- Individual Effects (DRIVE) model and well-being process questionnaire (WPQ). Psychology. 2017;8: 1919-1940.

Available:https://doi.org/10.4236/psych.201 7.812124

9. Smith AP, Smith HN. An international survey of the wellbeing of employees in the business process outsourcing industry. Psychology. 2017;8:160-167. DOI: 10.4236/psych.2017.81010

10. Smith AP, Smith HN. Workload, fatigue, and performance in the rail industry. In: Longo L. and Leva M.C. (eds.) Human Mental Workload: Models and Applications. H-WORKLOAD 2017. Communications in Computer and Information Science. Springer, Cham. 2017;726:251-263.

DOI: 10.1007/978-3-319-61061-0_17

11. Smith AP, Smith HN. A short questionnaire to measure wellbeing at work (ShortSWELL) and to examine the interaction between the employee and organization. In: Charles, R. \& Wilkinson, J. (Eds.) Contemporary Ergonomics and Human Factors 2017. Chartered Institute of Ergonomics and Human Factors. 2017; 200-205.

12. Fan J, Smith AP. The impact of workload and fatigue on performance. In: Longo $L$. and Leva M.C. (Eds.) Human Mental Workload: Models and Applications. HWORKLOAD 2017. Communications in Computer and Information Science. Springer, Cham. 2017;726:90-105.

DOI: 10.1007/978-3-319-61061-0_6

13. Fan J, Smith AP. Positive well-being and work-life balance among UK railway staff. 
Open Journal of Social Sciences. 2017;5: 1-6.

Available:http://dx.doi.org/10.4236/jss.2017 .56001

14. Jones MC, Johnston DW. Distress, stress and coping in first-year student nurses. Journal of Advanced Nursing. 1997;26(3): 475-482.

DOI:10.1046/j.1365-2648.1997.t01-500999.x

15. Bayram N, Bilgel N. The prevalence and socio-demographic correlations of depression, anxiety, and stress among a group of university students. Social Psychiatry and Psychiatric Epidemiology. 2008;43(8):667-672.

DOI: $10.1007 / \mathrm{s} 00127-008-0345-x$

16. Dahlin M, Joneborg N, Runeson B. Stress and depression among medical students:
A cross-sectional study. Medical Education. 2005;39(6):594-604.

DOI: 10.1111/j.1365-2929.2005.02176.x

17. Williams GM, Pendlebury $\mathrm{H}$, Thomas $\mathrm{K}$, Smith AP. The student well-being process questionnaire (student WPQ). Psychology. 2017;8(11):1748.

18. Galvin J. A multi-method approach to researching stress and mental health in two groups of healthcare students: nursing students and trainee clinical psychologists. Ph.D. Thesis. Cardiff University; 2016.

Available:https://orca-

mwe.cf.ac.uk/98616/1/2017galvinphd.pdf

19. Smith AP. Cognitive fatigue and the wellbeing and academic attainment of university students. Journal of Education, Society and Behavioural Science; 2018. DOI: 10.9734/JESBS/2018/39529

(c) 2018 Williams and Smith; This is an Open Access article distributed under the terms of the Creative Commons Attribution License (http://creativecommons.org/licenses/by/4.0), which permits unrestricted use, distribution, and reproduction in any medium, provided the original work is properly cited.

Peer-review history:

The peer review history for this paper can be accessed here: http://www.sciencedomain.org/review-history/23889 